\title{
Bacteria and viruses in the upper respiratory tract of Congolese children with radiologically confirmed pneumonia
}

\author{
Archippe M. Birindwa 1,2,3,6*0 , Jerry K. Kasereka ${ }^{2,3}$, Lucia Gonzales-Siles ${ }^{1}$, Shadi Geravandi ${ }^{1}$, Mambo Mwilo ${ }^{2,3}$, \\ Léonard K. Tudiakwile,3, Néné L. Mwinja ${ }^{2,3}$, Balthazar Muhigirwa², Théophile Kashosi ${ }^{3}$, Jeanière T. Manegabe ${ }^{2}$, \\ Elie B. Bugashane ${ }^{2}$, Stay M. Saili², Clement Mungo ${ }^{2}$, Rickard Nordén ${ }^{1,4}$, Rune Andersson ${ }^{1,4,5}$ and \\ Susann Skovbjerg ${ }^{1,4,5}$
}

\begin{abstract}
Background: Acute pneumonia remains a leading cause of death among children below 5 years of age in the Democratic Republic of the Congo (DR Congo), despite introduction of the 13-valent pneumococcal conjugate vaccine (PCV13) in 2013. Potential pathogens in the nasopharynx of hospitalised children with pneumonia have not been studied previously in DR Congo. Here we compare clinical characteristics, risk factors and nasopharyngeal occurrence of bacteria and viruses between children with severe and non-severe pneumonia.

Methods: Between June 2015 and June 2017, 116 children aged from 2 to 59 months hospitalised due to radiologically confirmed pneumonia at Panzi referral university hospital, Bukavu, Eastern DR Congo were included in the study and sampled from nasopharynx. A multiplex real-time PCR assay for detection of 15 different viruses and 5 bacterial species was performed and another multiplex PCR assay was used for pneumococcal serotype/serogroup determination.
\end{abstract}

Results: During the study period 85 (73\%) of the children with radiologically confirmed pneumonia met the WHO classification criteria of severe pneumonia and 31 (27\%) had non-severe pneumonia. The fatality rate was $9.5 \%$. Almost all (87\%) children were treated with antibiotics before they were hospitalised, in most cases with amoxicillin (58\%) or trimethoprim-sulfamethoxazole (20\%). The frequency of potential pathogens in the nasopharynx of the children was high, and any viral or bacterial nucleic acids present at high levels, irrespective of species or type, were significantly associated with severe pneumonia as compared with non-severe cases ( $52 \%$ versus $29 \%, p=0.032$ ). White blood cell count $>20,000 / \mu \mathrm{L}$ and C-Reactive Protein $>75 \mathrm{mg} / \mathrm{dL}$ were associated with severe pneumonia at admission. Fatal outcome was in the multivariable analysis associated with having a congenital disease as an underlying condition. One or more pneumococcal serotypes/serogroups could be identified in 61 patients, and out of all identified serotypes 31/83 (37\%) were non-PCV13 serotypes.

Conclusions: The occurrence of any bacteria or any viruses at high levels was associated with severe pneumonia at admission. Children with congenital disorders might need a higher attention when having symptoms of acute respiratory infection, as developed pneumonia could lead to fatal outcome.

\footnotetext{
*Correspondence: birindwaarchippe@gmail.com

${ }^{1}$ Department of Infectious Diseases, Institute of Biomedicine, University

of Gothenburg, Gothenburg, Sweden

Full list of author information is available at the end of the article
}

(C) The Author(s) 2021. Open Access This article is licensed under a Creative Commons Attribution 4.0 International License, which permits use, sharing, adaptation, distribution and reproduction in any medium or format, as long as you give appropriate credit to the original author(s) and the source, provide a link to the Creative Commons licence, and indicate if changes were made. The images or other third party material in this article are included in the article's Creative Commons licence, unless indicated otherwise in a credit line to the material. If material is not included in the article's Creative Commons licence and your intended use is not permitted by statutory regulation or exceeds the permitted use, you will need to obtain permission directly from the copyright holder. To view a copy of this licence, visit http://creativecommons.org/licenses/by/4.0/. The Creative Commons Public Domain Dedication waiver (http://creativeco mmons.org/publicdomain/zero/1.0/) applies to the data made available in this article, unless otherwise stated in a credit line to the data. 
Keywords: Bacteria, Viruses, Nasopharynx, Radiologically confirmed pneumonia, Hospitalised children, Pneumococcal serotypes/serogroups, Democratic Republic of the Congo

\section{Background}

Acute pneumonia remains a leading cause of childhood morbidity and mortality worldwide [1] although the estimated number of pneumonia episodes in young children decreased from 180 million in 2000 to 140 million in 2015 [2]. Pneumonia caused deaths in 0.9 million children below five years worldwide in 2015 [3] and is a leading cause of death in young children in the Democratic Republic of the Congo (DR Congo) [2]. The country has the fourth highest absolute number of pneumonia-related deaths worldwide and the second highest in Africa for children under 5 years of age [2]. The incidence of clinical childhood pneumonia decreased in the DR Congo from over 400 cases per 1000 children and year in 2000 to less than 300 in 2015 [2]. However, acute lower respiratory infections (ALRI) caused $20 \%$ of deaths among children aged between 1 and 59 months in 2017, with a death rate of 9.4 per 1000 live births [4].

Approximately $60 \%$ of Congolese children with acute pneumonia are treated by inappropriate care providers, such as traditional practitioners, vendors of medicines, relatives or friends [5] and up to $40 \%$ do not have access to the correct antibiotic treatment [6]. Moreover, abuse of antibiotics is abundant due to self-medication or consulting a non-appropriate health care provider, as well as over-prescription by clinicians $[7,8]$.

The burden of bacterial pneumonia has been reduced significantly in children worldwide after the introduction of both conjugate Haemophilus influenzae type b and pneumococcal conjugate vaccines (PCVs) into the routine childhood immunisation programs [9]. However, Streptococcus pneumoniae (the pneumococcus) still remains an important cause of pneumonia in many settings $[1,10]$. The virulence of $S$. pneumoniae is largely due to its polysaccharide capsule which protects it from phagocytosis and elimination by the host immune system and is the basis for epidemiological categorization of the pneumococci into more than 100 different serotypes[11, 12]. In the Eastern DR Congo the 13-valent pneumococcal conjugate vaccine (PCV13) was introduced in 2013.

Nowadays, with the more frequent use of molecular diagnostics, respiratory viruses are increasingly detected among children with acute respiratory disease $[1,13]$. Respiratory syncytial virus (RSV) has been reported as the most common virus in children below one year of age hospitalized with ALRI [14, 15]; however, other respiratory viruses, such as influenza virus and enterovirus are frequently detected as well $[1,14-16]$. However, discerning the aetiology of childhood pneumonia is complex because respiratory pathogens, including a wide range of bacteria and viruses, are frequently found in healthy children $[14,15]$.

Increased knowledge surrounding the clinical presentation and pathogens present in children with acute pneumonia may improve future clinical management and prevention of the infection, not least in low-income settings such as DR Congo which not only has a high disease burden [2] but also high rates of antibiotic resistance in the pneumococci colonizing young children [17]. In DR Congo the antibiotic treatments available are entirely empiric due to insufficient microbiological diagnostics and, to our knowledge no studies exist which have assessed the burden of potential pathogens in children hospitalized due to acute respiratory infection. Our objective was to describe clinical characteristics and risk factors and to determine the occurrence of bacteria and viruses in the nasopharynx of hospitalised children with pneumonia in the Eastern DR Congo. We also aimed to relate these findings to the severity of the disease and outcomes.

\section{Methods \\ Study site}

The study was conducted at Panzi Hospital in Bukavu town in the South Kivu region of DR Congo, which served a population of 470,000 inhabitants including 89,000 children below 5 years in 2017. The hospital is the referral university hospital for three general hospitals, four health centres and eight dispensaries located in the catchment population area, but the hospital also receives patients from outside this area. Panzi Hospital has 69 paediatric beds with an emergency ward which has 12 beds for acute and severe cases requiring nasal oxygen therapy. The department has two trained paediatricians and four resident doctors. The hospital has a radiology department run by a trained senior specialist in radiology.

\section{Study patients}

Out of a total of 2322 children between 2 months and 5 years of age treated for any disease at the Emergency and admissions Unit, Paediatric Department, between June 2015 and June 2017, 184 were diagnosed with acute lower respiratory infections. Of these, 116 cases had pneumonia that was radiologically confirmed and these children were thus included in the study. Among 
the 116 included children 80 came from the hospital catchment population area whereas 36 children came from other locations, in most cases nearby rural areas. Children admitted for severe malaria with pneumonia as complication were not included due to difficulties differentiating infection from pulmonary oedema. The parents or guardians of five HIV-positive children declined participation in the study and were thus not included while another three HIV-positive children were included. Four patients referred from health centres to Panzi Hospital had X-ray confirmed pneumonia but were not treated at the hospital because of the cost of care that was regarded as too high and were therefore not included. The direct cost of 5 days' treatment for pneumonia at Panzi Hospital could amount to 150 US dollars.

Data were collected on age, sex, dates of admission, duration of hospital care, as well as underlying conditions, including malnutrition, HIV, sickle cell disease, cerebral palsy, post-neonatal anoxia and congenital diseases. The WHO child growth standards were used to evaluate the nutritional status of children by computing the Z-scores of weight-for-age and height-for-age [18].

Patients were classified according to the revised WHO classification for pneumonia. This encompasses nonsevere pneumonia with fast breathing and/or chest indrawings. Fast breathing was present when the respiratory rate was $\geq 50$ breaths per minute for infants between 2 and 12 months of age and $\geq 40$ breaths per minute for children between 12 months and 5 years of age [18]. Children were considered to have severe pneumonia when there were any additional danger signs (e.g. not able to drink or breastfeed, persistent vomiting, convulsions, lethargy or loss of consciousness, stridor in a calm child or severe malnutrition) [19].

Saturation of peripheral oxygen $\left(\mathrm{SpO}_{2}\right)$ was measured on admission by using a pulse oximeter (Handheld Pulse Oximeter 3.7vx1, Li-ion, Model No.AH-M1, Acare Technology Co., Ltd, London, UK). Venous blood samples were collected for measurement of white cell count and C-reactive protein. A nasopharyngeal swab was taken from all children in the study (see below). After a physical examination, radiologist reports and blood test analyses, all admissions were validated by the paediatrician. Lung auscultations were considered as abnormal if crackles and/or rhonchi were present.

Data on pre-hospitalisation use of antibiotics were obtained from the parent or guardian asked if any antibiotics were given to the child during the week in which the symptoms of pneumonia began, or from the referral note from any first-level health care facility. The use of antibiotics and nasal oxygen therapy during hospitalisation was also recorded.
Patient outcomes were grouped into the following three categories: survived without complications, survived with complications (e.g. pneumothorax, empyema, or pleural effusion) and death. The group surviving without complications included patients discharged with improvements and who had switched to oral antibiotic treatment. This group included those discharged against medical advice but who were receiving oral antibiotic treatment.

The study was approved by the Ethics Committee at the Université Catholique de Bukavu, DR Congo (UCB/ $\mathrm{CIE} / \mathrm{NC} / 22 / 2014)$, and the Regional Ethics Committee in Gothenburg, Sweden (Dnr: 504-16). The study was further approved by the South-Kivu province Health Organisation $(065 / \mathrm{CD} / \mathrm{DPS}-\mathrm{SK} / 2015)$ and by the Director of Panzi Hospital.

\section{Assessment of chest X-ray}

The diagnosis of pneumonia was confirmed by X-ray (Siemens-Elema AB, Solna Sweden) with anteroposterior and lateral chest radiographs obtained from all included children. The images were first analysed by the radiologist at Panzi Hospital who was trained in the standard interpretation of chest radiographs for the diagnosis of childhood pneumonia. The second and final validation was performed by a senior specialist radiologist according to the WHO standard interpretation of chest radiographs for the diagnosis of pneumonia in children. Pneumonia was confirmed by the presence of consolidation, infiltrates or effusion and these results were considered as chest X-ray confirmed pneumonia [20]. Pleural effusion was present when there were more than $1 \mathrm{~cm}$ fluid in the pleural space between the lung and chest wall [20].

\section{Nasopharyngeal specimen collection}

A nasopharyngeal sample was collected from all included children and transported to the Clinical Laboratory at Panzi Hospital for pneumococcal culture as previously described [17]. The nasopharyngeal samples were thereafter stored frozen at $-20{ }^{\circ} \mathrm{C}$ before shipment to the Department of Infectious Diseases, University of Gothenburg, Gothenburg, Sweden, where they were stored at $-80^{\circ} \mathrm{C}$ prior to the molecular analyses (see below).

\section{Bacterial and viral nucleic acid detection}

Nucleic acids were extracted from $200 \mu \mathrm{L}$ of the nasopharyngeal sample as described earlier [21]. Eluted nucleic acids were stored at $-20^{\circ} \mathrm{C}$ until further analysis.

A multiplex real-time PCR assay capable of detecting 20 different viruses and bacterial species (adenovirus, bocavirus, coronavirus 229E, HKU1, NL63 and OC43, enterovirus, influenza virus $\mathrm{A}$ and $\mathrm{B}$, human metapneumovirus, parainfluenza $1-3$, rhinovirus, RSV, 
Bordetella pertussis, Chlamydia pneumoniae, H. influenzae, Mycoplasma pneumoniae and S. pneumoniae) was performed as previously described [22]. A Cycle Threshold $(\mathrm{Ct})$-value $<40$ was classified a positive result with values of $\mathrm{Ct}<30$ indicating high levels of nucleic acids. Pneumococci were identified by $l y t A$ gene detection in nasopharyngeal samples. However, an additional three samples were considered positive for pneumococci consequent to $c p s A$ gene detection $(\mathrm{Ct}<40)$ in the serotype assay described below.

\section{Pneumococcal serotyping}

A multiplex real-time PCR assay capable of detecting 40 different pneumococcal serotypes/serogroups in addition to the $\operatorname{cps} A$ gene was used according to a previously published protocol [23].

\section{Data management and statistical analysis}

Descriptive analysis was performed using the SPSS package (version 24.0) for logistic regression analysis of the relationship between nucleic acid identification and symptoms, medical conditions or outcome. Differences in baseline data and clinical factors were analysed with Pearson's chi-square test, and medians were compared with Mann-Whitney U test. The proportions of detected bacteria and viruses in severe and non-severe pneumonia cases were compared by Pearson's chi-square or Fisher's exact test (if $\mathrm{n}<5$ ). Potential variables associated with differences between fatal and improving cases were assessed by odds ratios (OR) with $95 \% \mathrm{CI}$ and were tested by univariable analysis with the Pearson's chi-square or Fisher's exact test (if $\mathrm{n}<5$ ). Associations to fatal outcome with $p<0.2$ were re-analysed by multivariable analysis. A $p$-value of $<0.05$ was considered statistically significant.

\section{Results}

\section{Characteristics of the included children}

Two years after the introduction of PCV13 in the infant immunization program in the Eastern DR Congo, 125/2322 (5.4\%) of all children admitted to Panzi Hospital, DR Congo were diagnosed with radiologically confirmed pneumonia. Of these children, 116 were included in the present study (median age 12 months). Ninety-five $(82 \%)$ of the included children came from Bukavu town while 21 came from rural areas (Table 1).

Almost all the children 101 (87\%) were treated with antibiotics before hospital admission, according to the parent or guardian $(n=39)$ or the referral notes $(n=62)$. The most common pre-hospitalisation antibiotics were either amoxicillin/ampicillin/phenoxymethylpenicillin or trimethoprim-sulfamethoxazole (Table 1). Two thirds $(67 \%)$ of the children had received two or three doses of PCV13.
The main signs and symptoms noted during the physical examination at admission were fever or recent history of fever (96\%), abnormal lung auscultation (99\%), cough or recent history of cough (100\%), and rapid or difficult breathing (94\%). Malnutrition was present in 11 (9.5\%) of the patients. During hospital stay 53\% were treated with ceftriaxone and gentamicin whilst $40 \%$ received ampicillin and gentamicin (Table 1).

\section{Differences in clinical characteristics between children with severe and non-severe pneumonia}

According to the WHO pneumonia classification, 85/116 $(73 \%)$ of the children met the criteria for having severe pneumonia at admission whereas 31 (27\%) had nonsevere pneumonia. Between the two groups, there was no statistically significant difference in sex, age, living area or immunisation status, fever, cough or abnormal auscultation (data not shown). However, a white cell count of over $20,000 / \mu \mathrm{L}$ was significantly associated with severe pneumonia (OR 4.75; 95\%CI 1.0-21.6, $p=0.043$ ) (Table 1). CRP levels above $75 \mathrm{mg} / \mathrm{dL}$ were also significantly associated with severe pneumonia at admission (OR 38.9; 95\% CI 5.1-299, $p=0.0004$ ) while CRP levels below $25 \mathrm{mg} /$ $\mathrm{dL}$ were negatively associated with severe disease (OR 0.19 ; 95\% CI 0.08-0.48, $p=0.0003$ ) (Table 1). The median CRP level was much higher in children with severe pneumonia at admission as compared with the non-severe pneumonia cases while the difference in median concentration of the white cells were small between the two groups (Table 1). As expected, nasal oxygen therapy was more often used in children with severe pneumonia as compared to children with less severe disease (Table 1). Overall, pre-hospitalisation antibiotic treatment was more common among children with severe pneumonia than in children with non-severe disease. While penicillin and the penicillin derivatives amoxicillin or ampicillin were equally common in the two groups, trimethoprimsulfamethoxazole was more commonly used in children with severe pneumonia (OR 4.75; 95\%CI 1.04-21.6 as above) (Table 1). During hospital stay, ceftriaxone combined with gentamicin was more frequently used to treat the severe pneumonia cases than the children with nonsevere disease (Table 1).

\section{Bacteria and viruses found in the nasopharyngeal secretions}

From only one nasopharyngeal sample pneumococci could be isolated by culture. However, by real-time PCR, performed directly on the nasopharyngeal sample, pneumococci could be detected in almost all children (96\%), whereas $H$. influenzae was detected in $54 \%$ and B. pertussis in 10\% (Table 2). When employing a more stringent cut-off level $(\mathrm{Ct}<30)$, bacteria were found in $62 \%$ of the 
Table 1 Clinical characteristics of the children hospitalised due to severe versus non-severe pneumonia at Panzi Hospital, Bukavu, DR Congo between June 2015 and June $2017(n=116)$

\begin{tabular}{|c|c|c|c|c|c|}
\hline Factors & & $\begin{array}{l}\text { All cases } \\
n=116(\%)\end{array}$ & $\begin{array}{l}\text { Severe pneumonia } \\
n=85(\%)\end{array}$ & $\begin{array}{l}\text { Non-severe } \\
\text { pneumonia } \\
n=31(\%)\end{array}$ & $\begin{array}{l}\text { Univariable } \\
\text { analysis } \\
p \text {-value }\end{array}$ \\
\hline \multirow[t]{2}{*}{ Location of residence } & Bukavu urban area' & $95(82)$ & $69(81)$ & $26(84)$ & 0.73 \\
\hline & Bukavu rural area ${ }^{1}$ & $21(18)$ & $16(19)$ & $5(16)$ & 0.73 \\
\hline \multirow[t]{2}{*}{ Sex } & Boys & $61(53)$ & $43(51)$ & $18(58)$ & 0.47 \\
\hline & Girls & $55(47)$ & $42(49)$ & $13(42)$ & 0.47 \\
\hline \multirow[t]{6}{*}{ Age in months } & Median $[\mathrm{IQR}]^{2}$ & $12[8-36]$ & $13[8-36]$ & $12[9-36]$ & 0.98 \\
\hline & $\leq 6$ & $26(22)$ & $10(12)$ & $6(19)$ & 0.29 \\
\hline & $>6-12$ & $32(28)$ & $30(35)$ & $12(39)$ & 0.73 \\
\hline & $>12-24$ & $23(20)$ & $19(22)$ & $4(13)$ & 0.26 \\
\hline & $>24-36$ & $14(12)$ & $12(14)$ & $2(7)$ & 0.27 \\
\hline & $>36-60$ & $21(18)$ & $14(16)$ & $7(23)$ & 0.45 \\
\hline Undernutrition $^{3}$ & & $11(9)$ & $10(12)$ & $1(3)$ & 0.19 \\
\hline Other diseases ${ }^{4}$ & & $9(8)$ & $8(9)$ & $1(3)$ & 0.29 \\
\hline PCV13 vaccination ${ }^{5}$ & (2 or 3 doses) & $78(67)$ & $55(65)$ & $23(74)$ & 0.33 \\
\hline Gastro-intestinal symptoms ${ }^{6}$ & & $30(26)$ & $21(25)$ & $9(29)$ & 0.63 \\
\hline \multirow[t]{4}{*}{ White cells count ${ }^{\top}$ (cells $\left./ \mu \mathrm{L}\right)$} & Median [IQR] & 16 [14-20] & 17 [14-20] & $16[13-17]$ & 0.018 \\
\hline & $4000-15,000$ & $48(41)$ & $29(34)$ & $9(29)$ & 0.60 \\
\hline & $>15,000-20,000$ & $54(47)$ & $35(41)$ & $19(61)$ & 0.58 \\
\hline & $>20,000$ & $23(20)$ & $21(25)$ & $2(7)$ & 0.043 \\
\hline \multirow[t]{4}{*}{ C-Reactive Protein ${ }^{8}$ (mg/dL) } & Median [IQR] & $64[28-64]$ & $78[24-84]$ & $23[22-69]$ & 0.0004 \\
\hline & $<25$ & $46(40)$ & $25(29)$ & $21(68)$ & 0.0003 \\
\hline & $25-75$ & $21(18)$ & $12(14)$ & $9(29)$ & 0.07 \\
\hline & $>75$ & $49(42)$ & $48(56)$ & $1(3)$ & 0.0004 \\
\hline \multirow[t]{4}{*}{ Pre-hospitalisation antibiotic treatment } & No antibiotic & $15(13)$ & $6(7)$ & $9(29)$ & 0.003 \\
\hline & $\begin{array}{l}\text { Amoxicillin, ampicillin or phenoxym- } \\
\text { ethylpenicillin }\end{array}$ & $68(59)$ & $49(58)$ & $19(61)$ & 0.72 \\
\hline & Trimethoprim-sulfamethoxazole & $23(20)$ & $21(25)$ & $2(6)$ & 0.043 \\
\hline & Other antibiotics $^{9}$ & $10(9)$ & $9(11)$ & $1(3)$ & 0.23 \\
\hline \multirow[t]{3}{*}{ Antibiotic treatment during hospital stay } & Ampicillin and gentamicin & $46(40)$ & $25(29)$ & $4(13)$ & 0.07 \\
\hline & $\begin{array}{l}\text { Ceftriaxone and } \\
\text { gentamicin }\end{array}$ & $62(53)$ & $53(62)$ & $9(29)$ & 0.002 \\
\hline & Others $^{10}$ & $8(7)$ & $7(8)$ & $1(3)$ & 0.36 \\
\hline Nasal oxygen therapy & & $100(86)$ & $79(93)$ & $21(68)$ & 0.001 \\
\hline \multirow[t]{4}{*}{ Duration of hospital stay (days) } & Median [IQR] & $5[5-8]$ & $5[5-8]$ & $5[4,5]$ & 0.0001 \\
\hline & $1-5$ & $70(60)$ & $44(52)$ & $26(84)$ & 0.003 \\
\hline & $>5-10$ days & $38(33)$ & $34(40)$ & $4(13)$ & 0.009 \\
\hline & $>10$ days & $8(7)$ & $7(8)$ & $1(3)$ & 0.36 \\
\hline \multirow[t]{3}{*}{ Outcome } & Improved & $104(90)$ & $74(87)$ & $30(97)$ & 0.16 \\
\hline & Dead & $11(9)$ & $10(12)$ & $1(3)$ & 0.19 \\
\hline & Complications & $1(1)$ & $1(1)$ & $0(0)$ & - \\
\hline
\end{tabular}

\footnotetext{
${ }^{1}$ Bukavu urban area $(n=95)$ : Ibanda area, $n=80$; Kadutu area, $n=13$; and Bagira, $n=2$

${ }^{2}$ IQR interquartile range

${ }^{3}$ Undernutrition defined as weight for age or weight for height as a Z score $\leq-2$ standard deviations, determined by ENA for smart software 2011

${ }^{4}$ Other diseases (Congenital and others): sickle cell disease $(n=2)$, congenital cardiac disorder $(n=1)$, cerebral palsy $(n=2)$, Down syndrome $(n=1)$, and HIV ( $\left.=3\right)$

${ }^{5}$ PCV13 $=$ the 13-valent conjugate pneumococcal vaccine

${ }^{6}$ Gastro-intestinal symptoms: diarrhoea or vomiting

${ }^{7}$ The normal range of White cells count is $4000-10,000$ cells $/ \mu \mathrm{L}$

${ }^{8}$ The normal value for C-Reactive Protein is $<10 \mathrm{mg} / \mathrm{dL}$

${ }^{9}$ Other antibiotics (pre-hospitalisation antibiotic treatment): erythromycin $(n=5)$, ciprofloxacin $(n=3)$ or cloxacillin $(n=2)$
} 
Table 1 (continued)

${ }^{10}$ Others (antibiotic treatment during hospital stay): ciprofloxacin $(n=3)$ and cloxacillin $(n=5)$

Table 2 Real-time PCR using the cycle threshold (Ct) levels $<40$ and $\mathrm{Ct}<30$, respectively, for pathogen detection in nasopharyngeal secretions from hospitalised children 2 to 59 months of age with severe or non-severe radiologically confirmed pneumonia

\begin{tabular}{|c|c|c|c|c|c|c|c|c|c|}
\hline \multirow[t]{3}{*}{ Pathogens } & \multicolumn{9}{|c|}{ Number of cases (\%) } \\
\hline & \multicolumn{4}{|c|}{ Real-time PCR detection level $\mathrm{Ct}<30$} & \multicolumn{5}{|c|}{ Real-time PCR detection level $\mathrm{Ct}<40$} \\
\hline & $\begin{array}{l}\text { All } \\
\text { pneumonia } \\
\text { cases } \\
n=116\end{array}$ & $\begin{array}{l}\text { Severe } \\
\text { pneumonia } \\
\mathrm{n}=85\end{array}$ & $\begin{array}{l}\text { Non-severe } \\
\text { pneumonia } \\
n=31\end{array}$ & $p$-value & $\begin{array}{l}\text { All } \\
\text { pneumonia } \\
\text { cases } \\
n=116\end{array}$ & $\begin{array}{l}\text { Severe } \\
\text { pneumonia } \\
n=85\end{array}$ & $\begin{array}{l}\text { Non-severe } \\
\text { pneumonia } \\
n=31\end{array}$ & $p$-value & $\begin{array}{l}\text { Ct value, } \\
\text { median (severe/ } \\
\text { non-severe } \\
\text { pneumonia) }\end{array}$ \\
\hline \multicolumn{10}{|l|}{ Bacteria } \\
\hline $\begin{array}{l}\text { Streptococcus } \\
\text { pneumoniae }\end{array}$ & $61(53)$ & $44(52)$ & $17(55)$ & 0.76 & $111(96)$ & $81(95)$ & $30(97)$ & 0.72 & $30.8 / 30.4$ \\
\hline $\begin{array}{l}\text { Haemophilus } \\
\text { influenzae }\end{array}$ & $23(20)$ & $18(21)$ & $5(16)$ & 0.54 & $63(54)$ & $50(59)$ & $13(42)$ & 0.10 & $32.2 / 30.7$ \\
\hline $\begin{array}{l}\text { Bordetella } \\
\text { pertussis }\end{array}$ & $1(1)$ & $1(1)$ & $0(0)$ & - & $12(10)$ & $9(11)$ & $3(9)$ & 0.88 & $37.8 / 39.1$ \\
\hline $\begin{array}{l}\text { Chlamydia } \\
\text { pneumoniae }\end{array}$ & $0(0)$ & $0(0)$ & $0(0)$ & - & $5(4)$ & $3(4)$ & $2(6)$ & 0.49 & $34.7 / 34.9$ \\
\hline $\begin{array}{l}\text { Mycoplasma } \\
\text { pneumoniae }\end{array}$ & $0(0)$ & $0(0)$ & $0(0)$ & - & $4(3)$ & $3(4)$ & $1(3)$ & 0.93 & $31.5 / 36.2$ \\
\hline Any bacteria & $72(62)$ & $59(69)$ & $13(42)$ & 0.008 & $112(96)$ & $81(95)$ & $30(97)$ & 0.72 & - \\
\hline \multicolumn{10}{|l|}{ Viruses } \\
\hline Rhinovirus & $34(29)$ & $27(32)$ & $7(23)$ & 0.33 & $85(73)$ & $64(75)$ & $21(78)$ & 0.41 & $31.8 / 32.9$ \\
\hline Enterovirus & $2(2)$ & $1(1)$ & $1(3)$ & 0.47 & $20(17)$ & $16(19)$ & $4(13)$ & 0.45 & $36.8 / 34.7$ \\
\hline Adenovirus & $5(4)$ & $4(5)$ & $1(3)$ & 0.72 & $13(11)$ & $9(11)$ & $4(13)$ & 0.72 & $34.0 /-$ \\
\hline Bocavirus & $5(4)$ & $4(5)$ & $1(3.2)$ & 0.72 & $12(10)$ & $8(9)$ & $4(12.9)$ & 0.58 & $31.1 / 37.2$ \\
\hline $\begin{array}{l}\text { Parainfluenza } \\
\text { virus }\end{array}$ & $3(3)$ & $3(4)$ & $0(0)$ & - & $9(8)$ & $9(11)$ & $0(0)$ & - & $31.5 /-$ \\
\hline RSV & $5(4)$ & $4(5)$ & $1(3)$ & 0.72 & $8(7)$ & $7(8)$ & $1(3)$ & 0.36 & $27.9 / 28.2$ \\
\hline Coronavirus & $1(1)$ & $1(1)$ & $0(0)$ & - & $8(7)$ & $6(7)$ & $2(6)$ & 0.90 & $33.6 / 34.2$ \\
\hline $\begin{array}{l}\text { Influenza A } \\
\text { virus }\end{array}$ & $1(1)$ & $1(1)$ & $0(0)$ & - & $3(3)$ & $1(1)$ & $2(6)$ & 0.15 & - \\
\hline $\begin{array}{l}\text { Influenza B } \\
\text { virus }\end{array}$ & $0(0)$ & $0(0)$ & $0(0)$ & - & $1(1)$ & $1(1)$ & $0(0)$ & - & - \\
\hline $\begin{array}{l}\text { Human } \\
\text { metapneu- } \\
\text { movirus }\end{array}$ & $0(0)$ & $0(0)$ & $0(0)$ & - & $1(1)$ & $1(1)$ & $0(0)$ & - & - \\
\hline Any virus & $53(47)$ & $44(52)$ & $9(29)$ & 0.032 & $106(91)$ & $78(92)$ & $28(90)$ & 0.80 & - \\
\hline $\begin{array}{c}\text { Any bacteria } \\
\text { and virus }\end{array}$ & $29(25)$ & $24(28)$ & $5(16)$ & 0.18 & $104(90)$ & $76(89)$ & $28(90)$ & 0.88 & - \\
\hline
\end{tabular}

Bold indicates result with $\mathbf{p}$-value $<0.05$ that was considered statistically significant

samples; S. pneumoniae in 53\% of the cases, and $H$. influenzae in $20 \%$ (Table 2).

The most frequently detected virus was rhinovirus (73\%), followed by enterovirus (17\%), while RSV was found in only $7 \%$ of the cases and influenza virus was rare (Table 2). When only high levels of viral nucleic acids were considered (Ct-value $<30)$, rhinovirus was found in $29 \%$ of the cases, and only a few samples were positive for RSV and influenza virus, respectively (Table 2). No statistically significant differences were found in the frequencies nor in the $\mathrm{Ct}$ median levels for any of the detected bacterial species or viruses between severe and non-severe pneumonia cases. However, high levels (i.e. Ct-value $<30$ ) of any virus (OR 2.63; $p$-value $=0.032$ ) or any bacteria (OR 3.14; $p$-value $=0.008)$ present in the sample, regardless of 
type or species was significantly associated with severe pneumonia (Table 2).

\section{Serotypes/serogroups of the pneumococci detected by real-time PCR}

Out of the 111 nasopharyngeal samples that were positive for pneumococci $(\mathrm{Ct}<40), 83$ serotypes/serogroups could be identified in samples from 61 children while no serotype could be detected in secretions from the remaining 50 children. Two different serotypes/groups

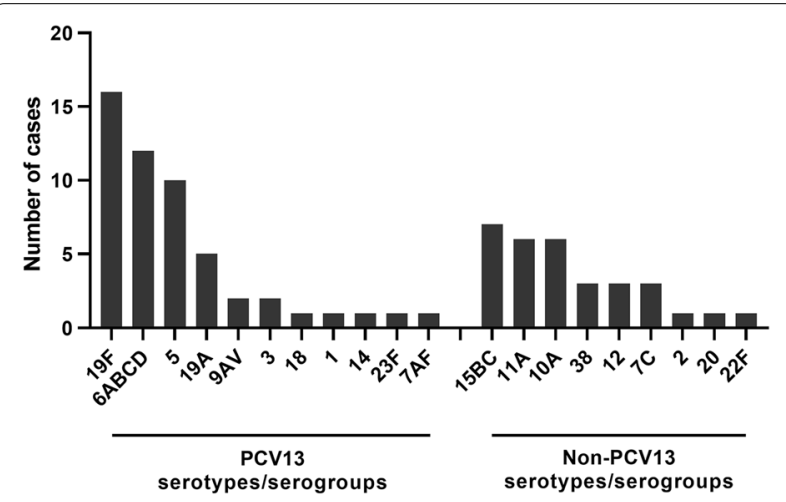

Fig. 1 Identification of 83 pneumococcal serotypes by real-time PCR in nasopharyngeal secretions from 61 children out of 116 hospitalised children with radiologic confirmed pneumonia. The method could not distinguish between the $6 A B C D$ serotypes, of which only $6 \mathrm{~A}$ and $6 \mathrm{~B}$ are in PCV13. Nor could the method separate $9 A V$, of which only $9 V$ is in PCV13 could be identified in 11 patients, while three children had three, one child had four, and another child had five different serotypes/groups. Among the 83 identified serotypes, 52 (63\%) belong to the PCV13 serotypes/ serogroups, while the remaining 31 (37\%) are nonPCV13 serotypes/serogroups. The serotypes/groups most frequently detected were 19F, 6ABCD and 5 while the predominant non-PCV13 serotypes were 15BC, $10 \mathrm{~A}$ and 11A (Fig. 1). Two samples were found to be negative for the cps A pneumococcal capsule gene but were strongly positive for the lytA gene $(\mathrm{Ct}<30)$, indicating non-encapsulated non-typeable pneumococci.

\section{Fatal outcome}

The overall case fatality rate among the hospitalized children with radiological confirmed pneumonia was $9.5 \%$ (11 children). Five of these children died within $48 \mathrm{~h}$ after hospital admission and another four died after two to five days. Fatal outcome was significantly associated with having a congenital disease as an underling condition (Table 3). Univariable analysis also showed an association between fatal outcome and high nucleic acid levels $(\mathrm{Ct}<30)$ of pneumococci or $\mathrm{RSV}$ in the upper respiratory tract of the children, but this could not be confirmed in the multivariable analysis (Table 3). The two RSV-positive cases with fatal outcome were also positive for pneumococci. Two different pneumococcal serotypes could be determined in the nasopharyngeal secretions from the children with

Table 3 Clinical characteristics, risk factors and microbiological findings among the children with fatal outcome compared to improved children hospitalized due to radiologically confirmed pneumonia $(n=116)$

\begin{tabular}{|c|c|c|c|c|c|c|}
\hline \multicolumn{2}{|c|}{ Clinical characteristics/risk factors/microbiological findings } & \multicolumn{2}{|l|}{ Outcome } & \multirow[b]{2}{*}{ OR $(95 \% \mathrm{Cl})$} & \multirow[b]{2}{*}{$p$-value } & \multirow[b]{2}{*}{$\begin{array}{l}\text { Adjusted } \\
p \text {-value }\end{array}$} \\
\hline & & Dead $(n=11)$ & Improved $(n=104)$ & & & \\
\hline \multirow[t]{2}{*}{ In hospital antibiotic treatment } & Ceftriaxone + gentamicin & $6(55)$ & $56(54)$ & $1.02(0.29-3.58)$ & 0.96 & \\
\hline & Ampicillin + gentamicin & $5(45)$ & $41(39)$ & $1.28(0.36-4.47)$ & 0.69 & \\
\hline Nasal oxygen ${ }^{1}$ & & $10(91)$ & $89(86)$ & $1.68(0.20-14.14)$ & 0.63 & \\
\hline \multirow[t]{2}{*}{ Underlying conditions } & Congenital diseases $^{2}$ & $4(36)$ & $5(5)$ & $15.84(3.22-77.86)$ & 0.0007 & 0.004 \\
\hline & Malnutrition ${ }^{3}$ & $2(18)$ & $9(9)$ & $2.34(0.43-12.55)$ & 0.31 & \\
\hline \multirow[t]{5}{*}{ Positive real-time PCR (Ct-values < 30) } & Streptococcus pneumoniae & $10(91)$ & $51(49)$ & $10.39(1.28-84.12)$ & 0.028 & 0.81 \\
\hline & Haemophilus influenzae & $3(27)$ & $20(19)$ & $1.57(0.38-6.47)$ & 0.52 & \\
\hline & Rhinovirus & $3(27)$ & $31(30)$ & $0.88(0.21-3.55)$ & 0.86 & \\
\hline & RSV & $2(18)$ & $3(3)$ & $7.48(1.10-50.76)$ & 0.039 & 0.99 \\
\hline & $\begin{array}{l}\text { At least one bacteria + at } \\
\text { least one virus }\end{array}$ & $3(27)$ & $24(23)$ & $1.25(0.30-5.08)$ & 0.75 & \\
\hline \multicolumn{7}{|c|}{ Bold indicates result with $p$-value $<0.05$ that was considered statistically significant } \\
\hline \multicolumn{7}{|c|}{${ }^{1}$ Nasal oxygen treatment $=0.5-2 \mathrm{~L} / \mathrm{min}$} \\
\hline \multicolumn{7}{|c|}{${ }^{2}$ Congenital diseases $=$ sickle cell disease $(n=2)$, congenital cardiac disorder $(n=1)$, cerebral palsy $(n=2)$, Down syndrome $(n=1)$ and HIV $(n=3)$} \\
\hline \multicolumn{7}{|c|}{${ }^{3}$ Malnutrition defined as weight for age or weight for height as a Z score $\leq-2$ standard deviations, determined by ENA for smart software 2011} \\
\hline
\end{tabular}


fatal outcome; serotype $19 \mathrm{~F}$ in four cases and $15 \mathrm{BC}$ in one case. In the remaining five children with pneumococci detected, no serotype could be identified.

\section{Discussion}

This is the first study on hospitalised children with radiologically confirmed pneumonia in DR Congo in the PCV13 post-vaccine era. It includes both clinical and microbiological aspects. A majority (73\%) of the children were diagnosed as having severe pneumonia. The most common symptoms for both severe and non-severe pneumonia cases were fever, cough or abnormal auscultation, similar to that described in a Vietnamese [24] and a Tanzanian study [25]. High white cell counts $(>20,000$ cells $/ \mu \mathrm{L})$ and high CRP levels $(>75 \mathrm{mg} / \mathrm{dL})$ were associated with severe pneumonia at admission. Similar findings of elevated white cell counts in hospitalised children with pneumonia were reported from Senegal [26], as well as high CRP levels $(>80 \mathrm{mg} / \mathrm{dL}$ ) also being associated with radiologically confirmed pneumonia in Tanzanian children [15].

The case fatality rate in our study was $9.5 \%$, similar to findings from a Tanzanian district hospital (11\%) [25] but higher than those reported from hospitalised children in Cambodia (3.2\%) [27]. Up to 80\% of deaths in children with severe respiratory infections may occur outside hospitals in low-income countries [28]. It is possible that some children first receive self-medication by parents or guardians, first seeking care at a private pharmacy, traditional practitioner or at any other non-appropriate health care provider before attending professional health care facilities $[5,8,28-30]$. This is supported by the fact that less than half (42\%) of under-five children with suspected pneumonia in DR Congo were found to have been treated by a trained health care provider [8].

Eighty-seven percent of the children included in our study received pre-treatment with antibiotics, in most cases amoxicillin, ampicillin or phenoxymethylpenicillin (59\%) followed by trimethoprim-sulfamethoxazole (20\%). In $34 \%$ of the cases, information about pre-hospitalisation medication was obtained from patient or guardian reports only and no information was obtained on duration of the treatment. Earlier reports show that parent history of antibiotic treatment in children is not always reliable [31-33]. Bioassays for detection of antibiotic activity in urine or serum may be of value for assessment of pre-hospitalisation antibiotic use [34-36] but these were not performed in the present study. However, from earlier studies it is known that pre-hospitalisation medication is very common in low-income countries, especially when there is limited health care access and high availability of antibiotics [5, 8]. Fifteen years ago, it was found that trimethoprim-sulfamethoxazole and amoxicillin were frequently used in self-medication in Congolese children having cough with or without fever [5]. We have recently showed a high level of resistance against trimethoprim-sulfamethoxazole in pneumococci colonizing children in the general population in this area of DR Congo [17] and similar results were shown for healthy children in northern Tanzania [37]. Here we found that pre-hospitalisation medication by the oral broad spectrum antibiotic trimethoprim-sulfamethoxazole was more common in children with severe pneumonia than in children with non-severe disease. However, since no data was collected on the duration of symptoms or treatment, the clinical impact of this result should be interpreted with caution.

Recently the DR Congo introduced clinical guidelines for the management of pneumonia. However, the antibiotic management of severe pneumonia was not included. For optimizing antibiotic treatment regimens antimicrobial resistance testing and surveillance are needed, especially considering the high level of resistance to commonly used antibiotics in the country [17]. In the present study, ceftriaxone and gentamicin were the main antibiotics used for treating severe pneumonia. This corroborates the findings of a study in Senegal where more than $55 \%$ of pneumonia cases were treated with ceftriaxone $[26,38]$.

The low isolation rate of live pneumococcus $(0.9 \%)$ by culture in the present study may be explained by the high frequency of pre-treatment with antibiotics. The pneumococcal isolation rate was higher (21\%) among the 794 Congolese children from the general population included in our previous study; also, $7 \%$ of these children had been treated with antibiotics in the last month according to their parents or guardians [17]. If carried out before specimen collection, this is known to reduce the culture isolation rate of bacteria but has less impact on the detection rate by PCR [36, 39]. Here we detected pneumococci by PCR in almost all (96\%) nasopharyngeal secretions and $H$. influenzae in $54 \%$. This result corroborates findings from Zanzibar, Tanzania, in which pneumococci were found in $87 \%$ and $H$. influenzae in $77 \%$ of febrile children [15]. When employing a more stringent cut-off level, (i.e. Ct-value $<30$ ) in which only high amounts of microbial nucleic acids are identified, we found S. pneumoniae in 53\%, and H. influenzae in $20 \%$ of the cases. We could not show any significant differences between the age groups and presence of pathogens as reported in other studies $[40,41]$ nor an association between severity of disease and specific viruses or bacterial species as identified in the study. However, high levels of bacterial or viral nucleic acids in the nasopharynx (irrespective of the species or types) were associated with more severe pneumonia at admission, compared to less severe cases. 
This supports the importance of not only bacteria but also viruses in the development of severe pneumonia.

Surprisingly, our detection rate of $7 \%$ RSV was much lower than the $31 \%$ reported in a multicentre study in Africa and Asia [14]. This discrepancy might be explained by the geographic variability of pathogens [14] or to possible degradation of nucleic acids during transport and storage of the samples eventually affecting the level of detection. However, although only a few cases were detected, RSV was more prevalent in children that died, also having high nucleic acid levels of pneumococci. In the two fatal RSV-positive cases, pneumococci were also detected, supporting the evidence of RSV being associated with pneumococci in critical cases.

The frequent co-occurrence of viruses and bacteria in childhood pneumonia [14] has been associated with disease severity $[10,14]$. Infection with RSV facilitates colonisation with bacteria such as S. pneumoniae and $H$. influenzae in the nasopharynx of young children [42]. In addition, invasive pneumococcal infection increases during the seasonal peak of various respiratory viruses, including influenza virus and RSV [14].

Since we did not include a hospital based control group, and most of these pathogens are also prevalent in healthy children, it was not possible to discern the aetiology of the pneumonia cases in the present study, not even when only microbial nucleic acids in large amounts were considered [14, 15, 43].

PCV13 serotypes/serogroups were more commonly identified than non-PCV13 serotypes/groups (63\% versus $37 \%$ ). This was in contrast to a study performed in Mozambique, in which half of the identified pneumococcal serotypes were included in the vaccine [44]. However, we may have under-estimated the frequency of non-PCV13 serotypes. This is because our method could neither distinguish between the 6ABCD serotypes, (of which only $6 \mathrm{~A}$ and $6 \mathrm{~B}$ are in PCV13), or between $9 \mathrm{~A}$ and $9 \mathrm{~V}$ (of which only $9 \mathrm{~V}$ is in PCV13). Moreover, the assay measures all the serotypes included in the pneumococcal vaccines but few of the additional ones. This suggests that, because those 50 samples were positive for pneumococci according to our PCR assay, but were negative for the serotypes included in the detection panel, they may have contained non-vaccine serotype pneumococci. Thus, non-vaccine serotypes were most likely much more prevalent than we detected here. As seen in other studies non-vaccine serotypes are continually emerging after the introduction of PCV13 $[45,46]$. Here, serotype 19F was the most frequent PCV13 serotype, whereas serotypes $15 \mathrm{BC}, 11 \mathrm{~A}$ and $10 \mathrm{~A}$ were the most prevalent non-PCV13 serotypes. This was similar to our findings in the general child population in the same area [17]. In this way, similar information about serotype distribution was obtained from healthy children as from children with pneumonia requiring hospital stay.

Our study had several limitations. First, obtained swab specimens were stored at $-20{ }^{\circ} \mathrm{C}$ in DR Congo before being transported to Sweden for storage at $-80{ }^{\circ} \mathrm{C}$ prior to the molecular analyses. It cannot be excluded that bacterial or viral nucleic acids were degraded during transport and storage, possibly affecting the detection levels of DNA and RNA. Nonetheless, rhinovirus RNA and pneumococcal DNA were detected in the majority of samples indicating sufficient storage conditions of both types of nucleic acid species. Second, in addition to referral notes from primary health care facilities, data on pre-hospitalisation antibiotic treatment were collected by questioning the parents or guardians, which might lead to unreliable or incomplete data. No data were collected on duration of symptoms or treatment before coming to the hospital, which might have an impact of the outcome and severity of the disease. Finally, the study was performed at a referral university hospital where treatment was associated with an unneglectable cost, which might affect the representativeness in the area.

Strengths of the study included the broad range of potential pathogens that we were able to detect in the children, and presentation of pneumococcal serotype data, which are very scarce in this resource-limited setting. We included only radiologically confirmed pneumonia cases, since clinical diagnosis of childhood pneumonia is difficult and unspecific, which strengthen the validity of the results from the study.

\section{Conclusions}

Any high bacterial or viral nucleic acid levels were more often detected in children having severe pneumonia than in those with non-severe disease. RSV and influenza were rarely detected. White blood cell count $>20,000 / \mu \mathrm{L}$ and CRP levels $>75 \mathrm{mg} / \mathrm{dL}$ were associated with severe pneumonia at admission while congenital disease was associated with fatal outcome. Out of all identified pneumococcal serotypes/serogroups 37\% were not in PCV13.

\begin{abstract}
Abbreviations
CARe: Center for Antibiotic Resistance Research, Gothenburg; CDC: Centers for Disease Control and Prevention; Cl: Confidence interval; DR Congo: Democratic Republic of the Congo; ENA: Emergency Nutrition Assessment; EUCAST: European committee on antimicrobial susceptibility testing; HIV: Human immunodeficiency virus; OR: Odds ratio; PCV: Pneumococcal conjugate vaccine; PCV13: 13-Valent pneumococcal conjugate vaccine; TMP-SMX: Trimethoprim-sulfamethoxazole; WHO: World Health Organisation.
\end{abstract}

\section{Acknowledgements}

Acknowledgments to the Gothenburg University Research Fund for starting up research in global health. Our sincere appreciation is also due to all the 
staff at Panzi Hospital for their co-operation and collaboration in this study. We thank the staff at the Clinical Laboratory, Microbiology Department, at Panzi Hospital, especially Maombi Chibashimba Ezekiel and Mugisho Muhandule David, for assisting Balthazar in performing excellent lab work. We thank Shora Yazdanshenas for valuable laboratory work at the Department of Infectious Diseases, Gothenburg University

\section{Authors' contributions}

$\mathrm{SS}, \mathrm{RA}$ and RN designed and supervised the study. AMB, JM, EBB, and SSM obtained consent from the parents/guardians to participate, acquired information for the questionnaires and collected the samples. CM and JKK performed the X-ray interpretation at Panzi hospital in DR Congo. AMB, NLM, MM and LKT were in charge of clinical evaluation at admission and in hospital follow-up of patients included in the study. Further, AMB, BM, TK assisted by local lab-technicians performed the lab-work in DR Congo and SG, LG, ES and RN performed the lab-work in Sweden. AMB analysed the data with close communication with SS, RA and RN under the orientation of statistician at Goteborg University. AMB was mainly responsible for writing the manuscript which was critically revised by SS, RA, RN, and LG. All authors read and approved of the final manuscript.

\section{Funding}

Open access funding provided by University of Gothenburg. This study was supported by the Sahlgrenska Academy, University of Gothenburg. The funding body had no role in the design of the study, the collection, analysis, interpretation of data, nor in writing of the manuscript.

\section{Availability of data and materials}

The datasets used and analysed during the current study are available from the corresponding author on reasonable request.

\section{Declarations}

\section{Ethics approval and consent to participate}

The study was approved by the Commission Institutionelle d'Ethique (CIE) of the Université Catholique de Bukavu (N/Ref: UCB/CIE/NC/22/2014) in accordance to existing ethical guidelines in D.R Congo and the Swedish Regional Ethical Committee in Göteborg ( ${ }^{\circ}$ : 504-16). The South-Kivu provincial Medical Doctor of Health in Bukavu was informed and approved the study (Ref: 065/ CD/DPS-SK/2015). Informed oral and written consent was obtained from the accompanying parent or guardian of each child included in the study.

\section{Consent for publication}

Not applicable.

\section{Competing interests}

The authors declare they have no competing interests.

\section{Author details}

'Department of Infectious Diseases, Institute of Biomedicine, University of Gothenburg, Gothenburg, Sweden. ${ }^{2}$ Panzi Hospital, Bukavu, Democratic Republic of the Congo. 'Université Evangélique en Afrique, Bukavu, Democratic Republic of the Congo. ${ }^{4}$ Department of Clinical Microbiology, Sahlgrenska University Hospital, Region Västra Götaland, Gothenburg, Sweden. ${ }^{5}$ CARe - Centre for Antibiotic Resistance Research, Gothenburg University, Gothenburg, Sweden. ${ }^{6}$ Hôpital Général de Référence de Panzi, BP: 266, Bukavu, Democratic Republic of the Congo.

Received: 17 April 2020 Accepted: 12 August 2021 Published online: 19 August 2021

\section{References}

1. Scotta MC, Marostica PJ, Stein RT. Pneumonia in children. In: Kendig's disorders of the respiratory tract in children. Amsterdam: Elsevier; 2019. p. 427-438. e424.

2. McAllister DA, Liu L, Shi T, Chu Y, Reed C, Burrows J, Adeloye D, Rudan I, Black RE, Campbell H. Global, regional, and national estimates of pneumonia morbidity and mortality in children younger than 5 years between 2000 and 2015: a systematic analysis. Lancet Glob Health. 2019;7(1):e47-57.

3. Howie SR, Murdoch DR. Global childhood pneumonia: the good news, the bad news, and the way ahead. Lancet Glob Health. 2019;7(1):e4-5.

4. WHO: Estimates of child cause of death, Acute Respiratory Infection 2018 (http://apps.who.int/gho/data/node.main.ChildMort?lang=en).

5. Kabuya KMGBJBKSEKW: Gestion des médicaments des maladies de l'enfant au niveau communautaire en République Démocratique du Congo, Kinshasa, Décembre 2006/Rapport d'enquête. Programme de Gestion rationnelle des Produits pharmaceutiques Centre pour la Gestion des Produits pharmaceutiques Management Sciences for Health 2007.

6. Mary Carol Jennings M, MPH: Pneumonia and Diarrhea Progress Report: Driving Progress through Equitable Investment and Action. Scientific rapport. Johns Hopkins Bloomberg School of Public Health. 2017. https://www.jhsph.edu/ivac/wp-content/uploads/2018/04/IVAC2017-Pneumonia-Diarrhea-Progress-Report-2.pdf.

7. Ndol FMI, Bompeka FL, Dramaix-Wilmet M, Meert P, Malengreau M, Mangani NN, Tsobo FM, Koné D. L'automédication chez des patients reçus aux urgences médicales des Cliniques Universitaires de Kinshasa. Santé Publique. 2013;25(2):233-40.

8. Noordam AC, Carvajal-Velez L, Sharkey AB, Young M, Cals JW. Care seeking behaviour for children with suspected pneumonia in countries in sub-Saharan Africa with high pneumonia mortality. PLoS ONE. 2015;10(2):e0117919.

9. Wahl B, O'Brien KL, Greenbaum A, Majumder A, Liu L, Chu Y, Lukšić I, Nair H, McAllister DA, Campbell H. Burden of Streptococcus pneumoniae and Haemophilus influenzae type b disease in children in the era of conjugate vaccines: global, regional, and national estimates for 2000-15. Lancet Glob Health.2018;6(7):e744-e757. https://doi.org/10. 1016/S2214-109X(18)30247-X.

10. Bhuiyan MU, Snelling TL, West R, Lang J, Rahman T, Borland ML, Thornton R, Kirkham L-A, Sikazwe C, Martin AC, et al. Role of viral and bacterial pathogens in causing pneumonia among Western Australian children: a case-control study protocol. BMJ Open. 2018;8(3):e020646.

11. Geno KA, Gilbert GL, Song JY, Skovsted IC, Klugman KP, Jones C, Konradsen $\mathrm{HB}$, Nahm $\mathrm{MH}$. Pneumococcal capsules and their types: past, present, and future. Clin Microbiol Rev. 2015;28(3):871-99.

12. Ganaie F, Saad JS, McGee L, van Tonder AJ, Bentley SD, Lo SW, Gladstone RA, Turner P, Keenan JD, Breiman RF. A new pneumococcal capsule type, 10D, is the 100th serotype and has a large cps fragment from an oral streptococcus. MBio. 2020. https://doi.org/10.1128/mBio. 00937-20.

13. Hasan R, Rhodes J, Thamthitiwat S, Olsen SJ, Prapasiri P, Naorat S, Chittaganpitch M, Henchaichon S, Dejsirilert S, Srisaengchai P. Incidence and etiology of acute lower respiratory tract infections in hospitalized children younger than 5 years in rural Thailand. Pediatr Infect Dis J. 2014;33(2):e45.

14. O'Brien KL, Baggett HC, Brooks WA, Feikin DR, Hammitt LL, Higdon MM, Howie SR, Knoll MD, Kotloff KL, Levine OS. Causes of severe pneumonia requiring hospital admission in children without HIV infection from Africa and Asia: the PERCH multi-country case-control study. The Lancet. 2019:394(10200):757-79.

15. Elfving K, Shakely D, Andersson M, Baltzell K, Ali AS, Bachelard M, Falk KI, Ljung A, Msellem MI, Omar RS. Acute uncomplicated febrile illness in children aged 2-59 months in Zanzibar-Aetiologies, antibiotic treatment and outcome. PLOS ONE. 2016;11(1):e0146054.

16. Ruuskanen O, Lahti E, Jennings LC, Murdoch DR. Viral pneumonia. The Lancet. 2011;377(9773):1264-75.

17. Birindwa AM, Emgård M, Nordén R, Samuelsson E, Geravandi S, GonzalesSiles L, Muhigirwa B, Kashosi T, Munguakonkwa E, Manegabe JT. High rate of antibiotic resistance among pneumococci carried by healthy children in the eastern part of the Democratic Republic of the Congo. BMC Pediatr. 2018:18(1):361.

18. Organization WH: Revised WHO classification and treatment of pneumonia in children at health facilities: evidence summaries. 2014

19. Organization WH. Revised WHO classification and treatment of childhood pneumonia at health facilities-evidence summaries. Geneva:WHO; 2014.

20. Organization $\mathbf{W H}$. Standardization of interpretation of chest radiographs for the diagnosis of pneumonia in children. Geneva: World Health Organization; 2001. 
21. Muhandule Birindwa A, Gonzales-Siles L, Nordén R, Geravandi S, Tumusifu Manegabe J, Morisho L, Saili Mushobekwa S, Andersson R, Skovbjerg S. High bacterial and viral load in the upper respiratory tract of children in the Democratic Republic of the Congo. PLoS ONE. 2020;15(10):e0240922.

22. Andersson ME, Olofsson S, Lindh M. Comparison of the FilmArray assay and in-house real-time PCR for detection of respiratory infection. Scand J Infect Dis. 2014;46(12):897-901.

23. Gonzales-Siles L, Salvà-Serra F, Degerman A, Nordén R, Lindh M, Skovbjerg S, Moore ER. Identification and capsular serotype sequetyping of Streptococcus pneumoniae strains. J Med Microbiol. 2019;68(8):1173-88.

24. Do AHL, van Doorn HR, Nghiem MN, Bryant JE, thi Hoang TH, Do QH, Le Van T, Tran TT, Wills B, van Nguyen VC. Viral etiologies of acute respiratory infections among hospitalized Vietnamese children in Ho Chi Minh City, 2004-2008. PLoS ONE. 2011;6(3):e18176.

25. Caggiano S, Ullmann N, De Vitis E, Trivelli M, Mariani C, Podagrosi M, Ursitti F, Bertolaso C, Putotto C, Unolt M. Factors that negatively affect the prognosis of pediatric community-acquired pneumonia in district hospital in Tanzania. Int J Mol Sci. 2017;18(3):623.

26. Fatou L. Etude des caractéristiques épidémiologiques, cliniques, radiologiques et évolutives des infections respiratoires aiguës basses (IRAB) au service de Pédiatrie du CHN de Pikine (Dakar/Senegal). Revue Africaine et Malgache de Recherche Scientifique/Sciences de la Santé. 2019;1(2).

27. Vong S, Guillard B, Borand L, Rammaert B, Goyet S, Te V, Lorn Try P, Hem $S$, Rith $S$, Ly $S$, et al. Acute lower respiratory infections in $\geq 5$ year-old hospitalized patients in Cambodia, a low-income tropical country: clinical characteristics and pathogenic etiology. BMC Infect Dis. 2013;13(1):97.

28. Nair H, Simões EA, Rudan I, Gessner BD, Azziz-Baumgartner E, Zhang JSF, Feikin DR, Mackenzie GA, Moiïsi JC, Roca A. Global and regional burden of hospital admissions for severe acute lower respiratory infections in young children in 2010: a systematic analysis. The Lancet. 2013;381(9875):1380-90.

29. Mande B, Tebandite K, Marini R, Alworonga O. Determinants of selfmedication of children by their parents at Kisangani. Asian J Res Med Pharm Sci. 2018. https://doi.org/10.9734/AJRIMPS/2018/41206.

30. Noordam AC, Carvajal-Velez L, Sharkey AB, Young M, Cals JW. Correction: care seeking behaviour for children with suspected pneumonia in countries in sub-Saharan Africa with high pneumonia mortality. PLoS ONE. 2015;10(4):e0126997.

31. Sombrero L, Sunico ME, Quiambao B, Lucero M, Gatchalian S, Leinonen M, Ruutu P. Reliability of parental history of antibiotic use for Filipino children admitted with acute lower respiratory tract infection. Am J Trop Med Hyg. 1999;60(3):397-9.

32. Khennavong M, Davone V, Vongsouvath M, Phetsouvanh R, Silisouk J, Rattana O, Mayxay M, Castonguay-Vanier J, Moore CE, Strobel M. Urine antibiotic activity in patients presenting to hospitals in Laos: implications for worsening antibiotic resistance. Am J Trop Med Hyg. 2011;85(2):295-302.

33. Saito $N$, Takamura N, Retuerma GP, Frayco CH, Solano PS, Ubas CD, Lintag AV, Ribo MR, Solante RM, Dimapilis AQ. Frequent community use of antibiotics among a low-economic status population in Manila, the Philippines: a prospective assessment using a urine antibiotic bioassay. Am J Trop Med Hyg. 2018;98(5):1512-9.

34. Liu Y-C, Huang W-K, Huang T-S, Kunin CM. Detection of antimicrobial activity in urine for epidemiologic studies of antibiotic use. J Clin Epidemiol. 1999;52(6):539-45.
35. Liu Y-C, Huang W-K, Huang T-S, Kunin CM. Extent of antibiotic use in Taiwan shown by antimicrobial activity in urine. The Lancet. 1999:354(9187):1360.

36. Driscoll AJ, Deloria Knoll M, Hammitt LL, Baggett HC, Brooks WA, Feikin DR, Kotloff KL, Levine OS, Madhi SA, O'Brien KL. The effect of antibiotic exposure and specimen volume on the detection of bacterial pathogens in children with pneumonia. Clin Infect Dis. 2017;64(suppl_3):S368-77.

37. Emgård M, Msuya SE, Nyombi BM, Mosha D, Gonzales-Siles L, Nordén R, Geravandi S, Mosha V, Blomqvist J, Franzén S. Carriage of penicillin-nonsusceptible pneumococci among children in northern Tanzania in the 13-valent pneumococcal vaccine era. Int J Infect Dis. 2019;81:156-66.

38. Knobbe RB, Diallo A, Fall A, Gueye AD, Dieng A, van Immerzeel TD, Ba A, Diop A, Diop A, Niang M. Pathogens causing respiratory tract infections in children less than 5 years of age in Senegal. Microbiol Insights. 2019;12:1178636119890885.

39. Park DE, Baggett HC, Howie SR, Shi Q, Watson NL, Brooks WA, Deloria Knoll M, Hammitt LL, Kotloff KL, Levine OS. Colonization density of the upper respiratory tract as a predictor of pneumonia-Haemophilus influenzae, Moraxella catarrhalis, Staphylococcus aureus, and Pneumocystis jirovecii. Clin Infect Dis. 2017;64(suppl_3):S328-36.

40. Nkwopara E, Schmicker R, Mvalo T, Phiri M, Phiri A, Couasnon M, McCollum ED, Ginsburg AS. Analysis of serious adverse events in a paediatric fast breathing pneumonia clinical trial in Malawi. BMJ Open Respir Res. 2019;6(1):e000415.

41. Nguyen PT, Tran HT, Fitzgerald DA, Tran TS, Graham SM, Marais BJ. Characterisation of children hospitalised with pneumonia in central Vietnam: a prospective study. Eur Respir J. 2019. https://doi.org/10.1183/13993003. 02256-2018.

42. Chappell K, Brealey J, Mackay I, Bletchly C, Hugenholtz P, Sloots T, Sly P, Young P. Respiratory syncytial virus infection is associated with increased bacterial load in the upper respiratory tract in young children. J Med Microbiol Diagn. 2013;1:1-9.

43. Pan $\mathrm{H}$, Cui B, Huang Y, Yang J, Ba-Thein W. Nasal carriage of common bacterial pathogens among healthy kindergarten children in Chaoshan region, southern China: a cross-sectional study. BMC Pediatr. 2016;16(1):161.

44. Adebanjo T, Lessa FC, Mucavele H, Moiane B, Chauque A, Pimenta F, Massora S, Carvalho MDG, Whitney CG, Sigauque B. Pneumococcal carriage and serotype distribution among children with and without pneumonia in Mozambique, 2014-2016. PLoS ONE. 2018;13(6):e0199363.

45. Kaur R, Casey JR, Pichichero ME. Emerging Streptococcus pneumoniae strains colonizing the nasopharynx in children after 13-valent (PCV13) pneumococcal conjugate vaccination in comparison to the 7-valent (PCV7) era, 2006-2015. Pediatr Infect Dis J. 2016;35(8):901.

46. Fan RR, Howard LM, Griffin MR, Edwards KM, Zhu Y, Williams JV, Vidal JE, Klugman KP, Gil Al, Lanata CF. Nasopharyngeal pneumococcal density and evolution of acute respiratory illnesses in young children, Peru, 2009-2011. Emerg Infect Dis. 2016;22(11):1996.

\section{Publisher's Note}

Springer Nature remains neutral with regard to jurisdictional claims in published maps and institutional affiliations.

Ready to submit your research? Choose BMC and benefit from:

- fast, convenient online submission

- thorough peer review by experienced researchers in your field

- rapid publication on acceptance

- support for research data, including large and complex data types

- gold Open Access which fosters wider collaboration and increased citations

- maximum visibility for your research: over $100 \mathrm{M}$ website views per year

At BMC, research is always in progress.

Learn more biomedcentral.com/submissions 